\title{
Strategi Pemasaran Pendidikan Madrasah Tsanawiyah Bali Bina Insani di Daerah Minonitas-Muslim Tabanan Bali
}

\author{
Syaifuddin ${ }^{a)}$, Muhammad Fahmi ${ }^{\text {b) }}$, Hanik Yuni Alfiyah ${ }^{\text {() }}$, Ilun Mualifah ${ }^{\text {d) }}$, M. Fadli Havera ${ }^{\mathrm{e}}$ \\ a) UIN Sunan Ampel Surabaya \\ b) UIN Sunan Ampel Surabaya \\ c) UNSURI Surabaya \\ d) UIN Sunan Ampel Surabaya \\ e) STAI Taruna Surabaya
}

\section{ABSTRAK}

Artikel ini merefleksikan kajian pemasaran pendidikan (marketing of education) Madrasah Tsanawiyah Bali Bina Insani (BBI). Berlokasi di daerah Muslim sebagai minoritas, lembaga ini menerapkan strategi pemasaran yang berimplikasi pada penerimaan masyarakat terhadap lembaga pendidikan Islam tersebut. Kajian ini mengeksplorasi strategi MTs. BBI dalam memasarkan lembaga pendidikannya melalui promosi secara halus namun terstruktur. Keberhasilan lembaga BBI ditandai dengan sikap penerimaan masyarakat yang mendukung keberadaan BBI melalui aksi-aksi kolektif. Sebagai aksi manajerial dalam mengelola perbedaan keagamaan dengan masyarakat sekitar, civitas akademik BBI dituntut bersikap terbuka dan akomodatif terhadap perbedaan. Budaya dasar ini bersama dengan pengelolaan yang profesional dan transparan menjadi nilai utama dalam pemasaran lembaga melalui media-media digital.

\section{ABSTRACT}

This article reflects the study of marketing of education at Madrasah Tsanawiyah Bali Bina Insani (BBI). Located in a Muslim minority area, this institution implements marketing strategy that has implications in people's acceptance towards the Islamic educational institution. This study explores the MTs BBI strategy in marketing its institution through smooth but structured promotion. The success of the $\mathrm{BBI}$ institution is marked by the attitude of community acceptance that supports the existence of BBI through collective actions. As a managerial action in managing religious differences within surrounding community, the $\mathrm{BBI}$ academic community is required to be open and accommodating towards differences. This basic culture together with professional and transparent management becomes the main value in the marketing of institutions through digital media.

\section{KATA KUNCI}

Pemasaran Pendidikan; Strategi; Kawasan Minoritas Muslim.

\section{KEYWORDS}

Marketing of Education; Strategy; Muslim Minority Area.

\section{A. Pendahuluan}

Diskursus tentang marketing of education (pemasaran pendidikan) lembaga pendidikan Islam khususnya lembaga madrasah tampak belum terlalu banyak menjadi bahan kajian serius atau mungkin relatif diabaikan oleh para sarjana maupun pengelola lembaga-lembaga pendidikan Islam (baca: madrasah). Pasalnya, masih banyak pihak yang beranggapan bahwa istilah bisnis seperti pemasaran relatif tidak tepat jika dibawa dalam lingkup madrasah, bahkan cenderung terkesan adanya unsur yang hendak mengkomersialkan institusi madrasah yang tentu saja bertentangan dengan pernyataan kebanyakan para pengelola madrasah, bahwa madrasah adalah suatu usaha amal sosial. 
Syaifuddin, et. al.

Padahal, sesungguhnya tidaklah sama dan sebangun antara pemasaran dengan komersial. Pemahaman bahwa pemasaran dalam pendidikan tidaklah mutlak harus berhubungan dengan kegiatan bisnis dan menjadikan pendidikan sebagai sesuatu komoditas tentu dapat diterima. Kegiatan bisnis dapat dilakukan pada dua sektor yaitu sektor yang mencari profit dan non-profit. Adapun mengenai lembaga pendidikan Islam (termasuk madrasah) adalah termasuk pada lembaga non-profit.

Berdasarkan pemahaman tersebut diatas, para pengelola madrasah harus bersedia untuk lebih terbuka dan tidak perlu merasa alergi terhadap konsep pemasaran yang akhir-akhir ini mulai gencar digulirkan ke dalam ranah pendidikan, karena justru melalui pemahaman dan penerapan teori-teori tentang pemasaran inilah setiap lembaga madrasah akan lebih terbantu dalam menghadapi ketatnya iklim arus persaingan di era globalisasi sekarang ini.

Pada dasarnya madrasah memiliki potensi yang sangat besar. Meski demikian, madrasah juga tidak luput dari berbagai problem dan tantangan serta kritik terhadap citra eksistensi lembaganya di tengah arus persaingan global yang semakin ketat. ${ }^{1}$ Diantara problem riil yang menjadi tantangan penting bagi setiap lembaga madrasah, misalnya, pasca UUSPN nomor 20 tahun 2003 madrasah tampak masih belum mampu memacu ketertinggalannya dalam pengelolaan sistem pendidikan.

Madrasah juga masih dipandang sebagai sekolah kelas kedua (second class) setelah sekolah umum. Hal ini dikarenakan kualitas layanan pendidikan yang diberikan oleh mayoritas madrasah masih dinilai orang lebih rendah daripada layanan pendidikan umum, khususnya negeri. Sehingga terkesan bahwa image madrasah itu "kurang" bermutu, berkualitas dan lulusannya kurang mempunyai daya saing. Penyebab kekurangmutuan ini bermacam-macam, ada yang disebabkan oleh manajemen (pengelolaan) pendidikannya yang kurang bagus, ada yang disebabkan oleh kualitas tenaga pengajarnya yang kurang baik, ada yang disebabkan oleh kekurangan dana operasional sehari-hari, dan ada pula yang karena ketiganya. Secara nasional tingkat favoritas masyarakat terhadap madrasah lebih rendah dibanding sekolah pada umumnya. ${ }^{2}$

Pada saat lembaga-lembaga madrasah masih mengalami problematika yang cukup kompleks, dewasa ini muncul kecenderungan (trend) baru pendidikan yang mencoba mengintegrasikan sekolah umum dengan sekolah Islam (madrasah) di berbagai daerah, seperti TK IT, SD IT, SMP IT, SMA IT, SMK IT, dan lain sebagainya. Kemunculan lembaga-lembaga ini terbukti telah cukup berhasil dalam membangun citra positif sebagai lembaga pendidikan Islam terpadu unggulan, sehingga lama kelamaan semakin membuat pamor madrasah tradisional semakin tergeser dari pentas pendidikan Islam. ${ }^{3}$

\footnotetext{
${ }^{1}$ Arief Furchan, Transformasi Pendidikan Islam di Indonesia; Anatomi Keberadaan Madrasah dan PTAI (Yogyakarta: Gama Media, 2004).

2 Imam Machali, Manajemen Pemasaran Jasa Pendidikan Madrasah, dalam Antologi Kependidikan Islam: Kajian Pemikiran Pendidikan Islam dan Manajemen Pendidikan Islam (Yogyakarta: Jurusan KI Fakultas Tarbiyah, 2010).

${ }^{3}$ Mahmud Arif, Panorama Pendidikan Islam di Indonesia; Sejarah, Pemikiran dan Kelembagaan (Yogyakarta: Idea Press, 2009).
} 
Lembaga-lembaga pendidikan Islam terpadu tersebut tentu memiliki suatu strategi tersendiri dalam memasarkan citra lembaganya kepada khalayak umum. Apalagi di tengah ketatnya iklim arus persaingan antar lembaga-lembaga pendidikan saat ini. Dinamika dalam mengimplementasikan pendekatan, praktik dan teknik pemasaran pendidikan sudah barang tentu menjadi bagian penting yang tidak dapat ditinggalkan atau diabaikan oleh lembaga-lembaga pendidikan Islam baru tersebut. Berdasarkan hal itulah, kajian tentang konsep dan strategi pemasaran dalam diskursus pendidikan Islam adalah sesuatu hal yang sudah tidak bisa ditawar-tawar lagi di era kontemporer (saat ini). Apalagi bagi lembaga pendidikan Islam yang berada di tengah mayoritas Non Muslim seperti di Kabupaten Tabanan Bali yang mayoritas beragama Hindu.

Di kabupaten Tabanan Bali Kecamatan Karambitan Desa Meliling, terdapat lembaga pendidikan Islam bernama Madrasah Tsanawiyah (MTs) Bali Bina Insani (BBI) yang dapat eksis meski berlokasi di tengah mayoritas masyarakat Non Muslim (Hindu). Madarasah ini didirikan pada tanggal 9 Agustus 1997. Madrasah ini di berdiri di komplek Pondok Pesantren Bali Bina Insani di bawah Yayasan La Royba. Tepatnya berlokasi di $\pm 11 \mathrm{~km}$ barat Kota Tabanan dan $\pm 32 \mathrm{~km}$ dari kota Denpasar.

Para siswa dan siswinya mayoritas berasal dari Propinsi Bali, tapi ada juga dari Propinsi-Propinsi lain di Indonesia, seperti dari Sumatera, Jawa, Lombok, NTT dan dulu banyak berasal dari Timor-Timor (sebelum berpisah dengan Indonesia). Pada awal berdirinya (1997), MTs BBI menerima siswa-siswa sejumlah 24 anak. Kemudian terus berkembang dan pada tahun 2000 jumlah siswa-siswi MTs BBI menjadi 62 anak (27 putra dan 35 putri). ${ }^{4}$ Saat ini jumlah siswa-siswinya tidak kurang dari 200 anak.

MTs BBI pembinaannya berada di bawah naungan Kementerian Agama dan Kementerian Pendidikan Nasional serta dididik oleh guru-guru berpengalaman dari sekolah-sekolah, baik dari lingkungan pesantren BBI maupun dari luar pesantren (termasuk guru umum negeri yang ada di Tabanan), sehingga dapat meluluskan siswa-siswinya setiap tahun dengan memuaskan. Madrasah ini memiliki fasilitas pembelajaran berupa: 7 ruang belajar, asrama putra, asrama putri, musholla, kantor, perpustakaan, mes guru, kolam lele, kantin, lapangan volly dan mobil antar jemput.

Hal yang menarik dari MTs BBI adalah, di tengah umat non Muslim (Hindu), ia tetap dapat eksis dengan jumlah siswa-siswi yang cenderung meningkat. Persoalannya adalah bagaimana strategi pemasaran lembaga tersebut di tengah mayoritas masyarakat Non Muslim? Bagaimanakah keberterimaan masyarakat Non Muslim Tabanan Bali tehadapnya? Apa saja faktor pendukung dan tantangan dalam kebertahanan dan pengembangannya? Hal-hal ini yang diuraikan pembahasannya dalam artikel ini.

\footnotetext{
${ }^{4}$ http://www.ppbalibinainsani.com (8 Maret 2018).
} 
Syaifuddin, et. al.

\section{B. Sekilas tentang Madrasah Tsanawiyah Bali Bina Insani (MTs. BBI)}

Madrasah Tsanawiyah (MTs.) Bali Bina Insani (BBI) adalah termasuk salah satu bagian dari lembaga pendidikan Madrasah yang berada di bawah naungan Pondok Pesantren Bali Bina Insani yang terletak $\pm 8 \mathrm{~km}$ dari pusat kota Tabanan. Posisi pondok pesantrennya terletak di tengah-tengah lingkungan dan masyarakat yang mayoritas beragama Hindu. Dengan demikian madrasah ini lokasinya berada di daerah non Muslim. ${ }^{5}$

Dengan alasan untuk menjaga keamanan dan kerukunan dengan lingkungan sekitar dan juga berkat semangat dari para dermawan dan juga pimpinan pondoknya dengan niat utama ingin mencerdaskan anak bangsa maka ada ide yang tumbuh untuk pondok pesantren tersebut yaitu mendirikan lembaga pendidikan sendiri dengan bantuan dana dari para dermawan/donator yang sudah banyak membantu dalam proses berdirinya pondok pesantren tersebut, kemudian lembaga tersebut diberi nama MTs. Bali Bina Insani.

MTs. Bali Bina Insani didirikan pada tanggal 9 Agustus tahun 1997, dengan Kepala Sekolah Ibu Etik Supriati, S.Pd, beliau menjabat selama satu tahun saja yaitu tahun pelajaran 1997-1998, kemudian pada bulan Agustus tahun 1998 digantikan oleh Bapak Haris Budi Santoso, S.Pd, beliau menjabat selama 6 tahun yaitu tahun 1998-2004, madrasah tersebut banyak kemajuan dengan kepemimpinan beliau, kemudian karena beliau diangkat menjadi kepala sekolah MA. Bali Bina Insani, maka pada tanggal 16 Agustus 2004 kepala sekolah MTs. Bali Bina Insani digantikan oleh ibu Dra. Isda Maini, masa kepemimpinan beliau hanya berlangsung selama satu tahun empat bulan saja yaitu sampai dengan 19 Nopember tahun $2005 .^{6}$

Kepemimpinan kepala sekolah kemudian digantikan oleh bapak Gufron Nurfat, S.Pd.I, beliau menjabat selama 2 tahun saja yaitu sampai tahun 2007 karena beliau menderita penyakit gagal ginjal dan beliau merasa sudah tidak sanggup untuk melanjutkan masa kepemimpinannya beliau mengundurkan diri yaitu tepatnya pada tanggal 1 Juli 2007, kemudian kepeminpinannya dilanjutkan dengan Bapak Mujiono Eko Susanto, S.Pd yang menjabat selama 5 tahun, Pegawai Negeri Sipil yang diperbantuakan, keadaan orang tua yang semakin renta membuat beliau harus mutasi dan tinggal dekat dengan orang tuanya yang berada di pulau Jawa, diapun berhasil mutasi dan digantikan oleh Bapak Yuli Saiful Bahri, S.Pd.I pada tanggal 20 Juni 2012, beliau menjabat sampai sekarang, Cita-cita dan impian menjadikan Madrasah berbasis Pesantren selalu menjadikannya semangat membangun MTs. Bali Bina Insani sebagai Madrasah bertaraf Nasional. ${ }^{7}$

Visi MTs. Bali Bina Insani adalah menjadi wadah dalam membentuk siswa "berprestasi, terampil, dan berbudaya berdasarkan Imtaq dan Iptek". Sedangkan misinya adalah: 1. Melaksanakan pembelajaran dan bimbingan secara efektif, sehingga setiap siswa berkembang secara optimal; 2 .

\footnotetext{
${ }^{5}$ Observasi pada 18 Agustus 2018.

${ }^{6}$ Profil Madrasah Tsanawiyah Bali Bina Insani, tahun 2018.

${ }^{7}$ Profil Madrasah.
} 
Mendorong dan membantu siswa untuk mengenali potensi dirinya, sehingga dapat dikembangkan secara optimal; 3. Melatih dan mengembangkan keterampilan berkomunikasi dalam bahasa asing; 4 . Meningkatkan dan pembiasaan disiplin dalam aktivitas kehidupan; 5. Menumbuhkan penghayatan terhadap ajaran agama Islam. ${ }^{8}$

\section{Strategi Marketing Education MTs. BBI di Daerah Non Muslim}

Madrasah Tsanawiyah Bali Bina Insani (MTs. BBI) merupakan lembaga pendidikan Islam formal yang mengutamakan muatan kurikulum keagamaan daripada umum. Keberadaannya di tempat yang mayoritas non Muslim, bahkan hampir keseluruhannya Non Muslim; orang-orang Muslim relatif hanya mereka yang berada di lokasi madrasah yang memang dinaungi oleh pesantren. ${ }^{9}$

Berdasarkan lokasinya yang berada di tengah-tengah masyarakat Non Muslim inilah yang menjadikan tantangan tersendiri bagi MTs. BBI dalam memasarkan lembaga pendidikannya. Sangat tidak mudah memasarkan lembaga pendidikan Islam di daerah non Muslim. Meski demikian, pihak MTs. BBI tidak pernah patah semangat dalam melaksanakan pendidikannya dan memasarkan lembaganya dalam rangka mencari siswa meski dikelilingi oleh orang-orang Non Muslim.

Diantara strategi pemasaran pendidikan (marketing education) yang dilakukan MTs. BBI dalam mendapatkan siswa di lembaganya adalah melalui sosialisasi keberadaan lembaga melalui website, brosur, Whatsapp, media sosial (TV), jaringan alumni dan kolega. Sebagaimana yang diungkapkan oleh Purnomo dalam sebuah wawancara di lapangan:

"(Peneliti): Asalamualaikum, Pak Pur, lembaga ini kan dikelilingi oleh masyarakat yang beragama Hindu atau Non Muslim hampir 100\%, kemudian strategi untuk mencari siswanya bagaimana? (Responden): iya pak, diantara strategi yang dipakai adalah lewat jaringan pertemanan Pak H. Jamal ${ }^{10}$ sebagai ketua pengadilan agama, kan pasti banyak koleganya, kemudian lewat jaringan alumni juga. (Peneliti): kemudian jalan apa lagi yang ditempuh oleh pihak sekolah? (Responden): ... Di sini kan banyak guru yang beda agama, dan dapat hidup rukun, ini kemudian dikenal orang sebagai adanya praktik toleransi yang mengemuka di lembaga ini. Kemudian banyak stasiun TV swasta yang meliput keberadaan lembaga pondok ini, ada MNC TV, NET TV dan stasiun-stasiun televisi yang ada di Bali, banyak yang ikut menyiarkan, dari situ akhirnya banyak orang semakin tahu. Akhirya tertarik dan menyekolahkan anaknya di sini."11

Selain itu, banyak juga yang merasa simpati dengan gaya performance dan kepemimpinan Pak H. Jamal sehingga tertarik untuk menyekolahkan anaknya di lembaga MTs. Bali Bina Insani, sebagaimana ungkapan di bawah ini:

"Iya, ada juga yang gara-gara lihat TV pada waktu H. Ketut Jamal diwawancarai, lalu ada orangtua itu suka dengan gaya beliau untuk mendidik di pondok, akhirnya dari situlah semakin banyak yang mendaftarkan anaknya sekolah di sini, dari tahun kemarin itu kita tanpa menyebarkan brosur secara manual, biasanya kita ke masjid-masjid nempel brosur, untuk tahun ini, alhamdulillah tanpa kita harus

\footnotetext{
8 Profil Madrasah.

${ }^{9}$ Observasi.

${ }^{10}$ Pak H. Jamal (H. Imaduddin Jamal) adalah pendiri dan sekaligus pengasuh Pondok Pesantren Bali Bina Insani yang menaungi keberadaan MTs. Bali Bina Insani.

${ }^{11}$ Purnomo (Wakil Kesiswaan MTs. Bali Bina Insani), Wawancara pada 25 Agustus 2018.
} 
Syaifuddin, et. al.

menyebar brosur secara manual, ya itu berkat ada siaran televisi tentang lembaga ini. Penyebaran brosur pun cukup via online. Jadi biasanya tiap tahun membuat brosur dan disebar secara manual, tahun ini cukup mencetak brosur secukupnya lalu disebar lewat Watsapp, facebook, dan media online lainnya."12

Strategi pemasaran model $d$ atas cukup efektif, terbukti dengan adanya siswa-siswi yang semakin meningkat keberadaannya dari tahun ke tahun di madarasah ini. Jumlah kelas untuk MTs. Bali Bina Insani tahun ini sebanyak 5 kelas untuk 125 siswa-siswi baru. Ini meningkat tajam dari tahun sebelumnya yang berjumlah 3 kelas untuk siswa-siswi baru. ${ }^{13}$ Meski MTs. Bali Bina Insani termasuk dalam kelompok minoritas di daerah masyarakat sekitarnya, namun tetap dapat survive, eksis dan progresif. Memang ada tantangan tersendiri bagi komunitas minoritas dalam berkiprah di kelompok mayoritas yang berbeda faham dan ajaran. Namun hal itu bukan berarti tidak dapat diatasi.

Secara nasional, masyarakat Muslim adalah mayoritas, tetapi di Bali masyarakat Muslim adalah minoritas. Kajian tentang minoritas Muslim di sebuah wilayah belum banyak dilakukan. Padahal bagi Indonesia yang memiliki penduduk mayoritas Muslim terbesar di dunia, dinamika kehidupan sosial politik minoritas Muslim di berbagai daerah di Indonesia, perlu mendapat perhatian. ${ }^{14}$ Mereka menjadi salah satu perekat kehidupan bermasyarakat. Karena, apabila mereka luput dari perhatian nasional dan kemudian ada permasalahan lokal yang berkaitan dengan hubungan mayoritas-minoritas, maka kondisi tersebut dapat berpengaruh pada konstalasi politik nasional. Oleh karena itu, kajian dan pemahaman hubungan minoritas Muslim dan mayoritas Hindu di Bali menjadi penting untuk mengurangi beban yang harus ditanggung secara nasional.

Minoritas, meminjam pandangan Wirth, adalah sekelompok orang yang -karena karakteristik fisik dan kultural mereka- mendapat perlakuan berbeda dan tidak seimbang dari kelompok lain dalam masyarakat; dan yang menganggap diri mereka sebagai objek dari diskriminasi kolektif. Eksistensi minoritas dalam sebuah masyarakat berkaitan erat dengan eksistensi kelompok dominan yang menikmati status sosial yang lebih tinggi dan memiliki hak istimewa. ${ }^{15}$ Brown menegaskan bahwa anggota kelompok minoritas memiliki rasa aman ketika berada di dalam kelompok mereka sendiri dan bersikap patuh, baik secara implisit maupun eksplisit. ${ }^{16}$ Senada dengan Wirth, Foucault menyatakan bahwa istilah minoritas dipakai untuk membedakan karakteristik kelompok atau etnik yang menjadi subordinat dari kelompok lainnya. ${ }^{17}$

\footnotetext{
12 Purnomo.

${ }^{13}$ Yuli Saiful Bahri (Kepala MTs. Bali Bina Insani), Wawancara pada 25 Agustus 2018.

${ }^{14}$ M. Hamdan Basyar, Identitas Minoritas di Indonesia: Kasus Muslim Bali di Gianyar dan Tabanan (Jakarta: LIPI, 2010), 10.

${ }^{15}$ Barton Meyers, "Minority Group: An Ideological Formulation", Social Problems, Vol. 32, No. 1, Dilematic Issue on Minorities and Social Movements (October, 1984), 6.

${ }^{16}$ Meyers, “Minority Group: An Ideological Formulation," 7.

17 Nadir Salahuddin, Dinamika Konstruksi Identitas: Pengalaman Minoritas di Muangthai, Filipina dan Singapura, Makalah disampaikan dalam Diskusi Terbatas Minoritas Muslim di Asia Tenggara di IAIN Sunan Ampel (Surabaya 6 Juli 2000), dalam Tri Nuke Pujiastuti, Problematika Minoritas Muslim di Filipina, Thailand, dan Myanmar: Catatan Pendahuluan, dalam Riza Sihbudi (ed), Problematika Minoritas Muslim di Asia Tenggara: Kasus Mora, Pattani dan Rohingya (Jakarta: PPW-LIPI, 2000), 4-5.
} 
Begitu juga MTs. Bali Bina Insani, orang-orang di dalamnya merasa aman dan damai ketika berada di dalam komunitas sekolah atau kompleks pesantrennya. Akan tetapi ketika berbaur dengan masyarakat Hindu yang dominan di daerahnya, maka mereka pun harus banyak mengalah dan berusaha beradaptasi dengan kelompok mayoritas yang berbeda agama tersebut.

Di MTs. BBI kegiatan sekolah dimulai sejak pukul 07.00 WITA. Para siswa dan guru yang Muslim berkumpul di musholla untuka melakukan shalat dhuha. Lalu ada sedikit breafing sebelum masuk kelas. Sebelum masuk kelas, semua siswa bersalaman dengan para guru. Ketika ada guru beragama Hindu yang hadir, para siswa juga bersalaman dengan mereka. Rasa saling hormat-menghormati di antara mereka tampak sekali terlihat. ${ }^{18}$ Mereka tidak lagi dibatasi oleh skat agama yang berbeda tetapi membaur saling menghormati di antara satu dengan yang lain. hal ini sebagaimana dinyatakan oleh Yuli Saiful Bahri:

"Para siswa jam 7 sudah standby untuk shalat dhuhah berjamaah, lalu ada sedikit briefing, yang Tsanawiyah kita bersalaman dulu dengan semua dewan guru, yang Aliyah punya budaya tersendiri, ini semua untuk membangun konsep menghormati siswa kepada guru-guru, meski beragama Hindu, jadi kita mempunyai guru-guru Hindu yang tetap kita hormati sebagaimana menghormati guru-guru Muslim." 19

Saat ini ada perkembangan baru di MTs. BBI, yakni bertambahnya jumlah kelas untuk kelas 1 menjadi 5 kelas dari 3 kelas pada tahun ajaran sebelumnya. Jadi pada tahun ajaran 2018-2019 MTs. BBI memiliki 5 rombongan belajar (Rombel) untuk kelas 1 . Hal ini menunjukkan peningkatan jumlah siswa yang signifikan. Sehingga jumlah guru pun perlu tambahan. Maka pihak MTs. BBI membuka lowongan mengajar bagi guru-guru baru yang bersedia mengajar. Diantara para pelamar, ada sejumlah guru beragama Hindu yang melamar dan diterima menjadi bagian dari tenaga pengajar di Mts. BBI. Sehingga saat ini tidak kurang dari 9 guru beragama Hindu ikut mengajar di MTs. Bali Bina Insani. ${ }^{20}$

Guru-guru yang beragama Hindu diamanati untuk mengajar mata pelajaran umum, antara lain: olah raga, seni budaya, keterampilan, IPS, bahasa. Faktor yang melatari MTs. BBI menerima keberadaan guru-guru beragama Hindu karena memang dari sejarahnya lembaga ini sudah terbuka. Meski MTs. berada di dalam naungan Pondok Pesantren Bali Bina Insani, namun sejak berdirinya pesantren ini menerapkan konsep dan praktik ajaran yang toleran dan terbuka pada setiap keberagaman dan perbedaan. Yuli Saiful Bahri menyatakan:

"Madrasah atau sekolah formal ini awal berdirinya berangkat dari sebuah kebutuhan dan merupakan usulan Eyang Hj. Sofiya Dewa Pere (Pere itu nama suaminya, mantan tentara yang muallaf). Pada tahun 1995 para santri banyak yang sekolah di SMP. SMP yang paling dekat yaitu SMPN Karambitan yang jaraknya 2,5 km dari pesantren. Pada saat itu kepala sekolahnya beragama Hindu, dan masih keponakan dari salah satu pendiri lembaga kita, yaitu Eyang Hj. Sofiya. Setelah jadi muallaf kuat sekali agamanya. Dia punya tanah 4 are dan rumah seluas 2 are. Sesuatu disampaikan kepada istrinya agar tanah dan rumahnya jangan dijual, tetapi hendaknya dipergunakan untuk kegiatan perjuangan pendidikan Islam dalam bentuk apa saja. Setelah itu orangnya meninggal. Lalu suatu ketika ayahhanda Drs. H. Ketut Imaduddin Jamal menyampaikan pengajian pada tahun 1997 di depan masyarakat Muslim Sulawesi. Salah satu jama'ahnya adalah $\mathrm{Hj}$. Sofia. Materi yang disampaikan saat itu adalah surat al-Ma'un (pelayanan terhadap yatim piatu). Ba'da ta'lim Hj. Sofiya langsung maju menemui ayah Jamal dan berkata: "ustad anda mengajarkan al-Maun bagaimana cara melakukannya?" Saat itu beliau belum

\footnotetext{
18 Observasi pada 18 Agustus 2018.

${ }^{19}$ Yuli Saiful Bahri (Kepala MTs. Bali Bina Insani), Wawancara pada 25 Agustus 2018.

${ }^{20}$ Nur Fadhilah (Guru Sejarah Kebudayaan Islam MTs. BBI), Wawancara pada 25 Agustus 2018.
} 
punya konsep karena kami masih konsentrasi pada lembaga yang ada di Singaraja. Saya di Singaraja waktu itu, saya dari Darun Najah Jakarta disuruh membuat lembaga di sana. Di sana mayoritas muslim? 100\% Muslim tapi belum ada lembaga pesantren. Lalu kita rintis untuk ada. Suatu ketika ayah Jamal bercerita tentang tawaran $\mathrm{Hj}$. Sofiya terkait tanah 4 are dan bangunan rumah 2 are, kemudian kita chek kesana, dan kita dirikan pondok yatim yang kita beri nama "Pondok Yatama". Dari pondok yatim ini lalu kita dirikan pesantren. Kemudian kita rintis Madrasah Tsanawiyah dan Aliyah. Para perintis lembaga ini memang punya modal toleransi yang tinggi terhadap setiap perbedaan."21

Diantara modal dasar pemasaran lembaga MTs. BBI adalah adanya kebutuhan masyarakat Muslim. Pemasaran memang merupakan proses sosial berbasis manajerial, dimana individu dan kelompok memperoleh apa yang dibutuhkan dan diinginkan dengan membuat, menawarkan, dan menukarkan produk yang baik dengan para pihak. Hal ini sejalan dengan pandangan Kotler yang menyatakan bahwa pemasaran bersandar pada: kebutuhan (needs), permintaan (demands), keinginan (wants); produk (barang, jasa, pelanggan); nilai, biaya, kepuasan; pertukaran, transaksi; hubungan, jaringan; pasar, pemasar dan prospek. ${ }^{22}$

Semua siswa di Madrasah Tsanawiyah Bali Bina Insani (MTs. BBI) tinggal di asrama. Meski rumahnya dekat dengan pesantren, tetap harus tingal di pesantren. MTs. BBI berada di bawah naungan Pondok Pesantren Bali Bina Insani (PP BBI). PP BBI berada di bawah naungan Yayasan La Royba. Lembaga ini lokasinya berada di Desa Meliling Kecamatan Karambitan Kabupaten Tabanan Provinsi Bali. ${ }^{23}$

MTs. BBI berada di bawah naungan Yayasan La Royba. Nama La Royba ini merupakan hasil istikhoroh sang pendiri. Ketika itu pendiri minta toong agar dicarikan nama yayasan yang berbahasa Arab tapi tidak terlalu sulit untuk diucapkan orang yang bukan orang Arab. Belajar dari Gontor, di sana ada koperasi yang bernama "La Syakka". Lalu pendiri meminta untuk mencari nama yang artinya sama tapi lafadlnya berbeda. Lalu istikhoroh, setelah 3 bulan kumpul lagi, belum ada kesepakatan nama. Kemudian buka-buka al-Quran ketemu ayat "dzalikal kitabu la royba fiih" dalam surat al-Baqarah ayat 2. Pendiri kemudian jatuh cinta pada ayat itu, lalu diambillah kata "La Royba" dan dijadikanlah menjadi nama yayasan. Makna yang terkandung di dalamnya, jangan ragu-ragu untuk melangkah dalam memperjuangkan kebaikan agama. ${ }^{24}$

Setelah disepakati nama yayasan, lalu diurus legal formalnya ke notaries untuk dibuatkan akte pendirian, dqn dilanjutkan pengurusan legal formalnya ke Kemenkumham. Kemudian dilakukan audensi ke dinas sosial. Awalnya dinas social bingung terkait dengan apa yang akan dilakukan oleh yayasan La Royba. Kemudian pihak dinas sosial dipersilahkan untuk survey lokasi yayasan la Royba. Akhirnya, yayasan La Royba pun diizinkan untuk beroperasi dalam kegiatan-kegiatannya. ${ }^{25}$

Dari segi kepengurusan legal formal saja sudah agak sulit didapat mengingat lembaga ini bagian dari kelompok minoritas di tengah kelompok mayoritas yang berbeda agama dan keyakinan. Meski

\footnotetext{
${ }^{21}$ Yuli Saiful Bahri (Kepala MTs. Bali Bina Insani), Wawancara pada 25 Agustus 2018.

22 Philip Kotler, Manajemen Pemasaran (Jakarta: Prenhallindo, 1997), 7-8.

${ }^{23}$ Profil Madrasah Tsanawiyah Bali Bina Insani Yayasan La Royba, Tahun 2018.

${ }^{24}$ Yuli Saiful Bahri (Kepala MTs. Bali Bina Insani), Wawancara pada 25 Agustus 2018.

${ }^{25}$ FGD pada 1 September 2018.
} 
demikian, lembaga ini (Yayasan La Royba) yang kemudian menaungi MTs. BBI terus berjuang dalam beradaptasi dengan masyarakat sekitar yang agama dominannya adalah Hindu. Perjuangan tersebut berhasil dan setahap demi setahap lembaga ini berkembang, bahkan penerima manfaat dari lembaga ini terus meningkat.

Lembaga MTs. BBI terus berjuang dalam memasarkan lembaganya. Diantara strategi pemasarannya adalah memanfaatkan jaringan pertemanan, media sosial online, dan sebagainya. Lembaga memang perlu membangun banyak relasi jangka panjang sehingga memuaskan pihak konsumen dan distributor untuk mempertahankan preferensi dan order jangka panjang. Hal ini perlu diwujudkan dengan memberikan pelayanan yang baik, kualitas yang tinggi, harga yang terjangkau sesuai dengan kemapuan banyak orang.

\section{Penerimaan Masyarakat Non Muslim tehadap MTs. BBI}

Madrasah Tsanawiyah (MTs) Bali Bina Insani (BBI) merupakan pengembangan dari Pesantren Bali Bina Insani. Pesantren merupakan lembaga pendidikan Islam non formal yang tertua di Indonesia yang memiliki komponen: kyai, kitab kuning, siswa, asrama, dan masjid. ${ }^{26}$ Pondok pesantren kemudian banyak yang mengembangkan lembaganya dengan mendirikan madrasah/ sekolah sebagai lembaga pendidikan Islam formal. Meski madrasah tetap mempertahankan ciri khas tradisional pesantren, tapi di dalamnya ditambah mata pelajaran umum, sejalan dengan kurikulum nasional dan lokal. Hal ini juga terjadi pada MTs. BBI.

Tidak hanya mengembangkan lembaga berupa madrasah, pesantren semakin dinamis dan tidak sedikit yang mempunyai lembaga pendidikan formal mulai tingkat SD sampai Perguruan Tinggi. Madrasahsebagai lembaga non profit dan order pendidikan muncul sebagai bentuk pendidikan Islam formal dan perkembangan dari pesantren. Di madrasah berlaku proses komunikasi edukatif antara guru dan siswa dalam rangka mencapai tujuan pendidikan yang telah ditentukan. ${ }^{27}$ Kemunculan madrasah menjadi simbol kebangkitan daripada sistem pendidikan Islam, ${ }^{28}$ dan bentuk dinamika pesantren.

Paparan tersebut di atas menandakan bahwa kebanyakan pesantren bersifat dinamis. Keberadaan pesantren yang tetap dapat survive dan eksis hingga kini menjadi bukti bahwa pesantren menjadi bagian dari lembaga pendidikan yang responsif terhadap perkembangan dan kemajuan zaman. ${ }^{29}$ Para pegiat pesantren (pemangku, kiai, ustadz), termasuk pesantren yang menjadi payung MTs. BBI terbukti memiliki kualitas keterbukaan dan dinamika yang membuatnya tetap berlangsung secara eksis.

\footnotetext{
${ }^{26}$ Zamakhsyari Dhofier, Tradisi Pesantren: Studi tentang Pandangan Hidup Kiai, cet. VI (Jakarta: LP3ES, 1994), 18

${ }^{27}$ Ramayulis, IImu Pendidikan Islam (Jakarta: Kalam Mulia, 1994), 158.

${ }^{28}$ Abdullah Idi dan Toto Suharto, Revitaslisasi Pendidikan Islam (Yogyakarta: Tiara Wacana, 2006), 20.

${ }^{29}$ Hanun Asrohah, "The Dynamics of Pesantren: Responses toward Modernity and Mechanism in Organizing Transformation," Journal of Indonesian Islam, Vol. 05, No. 01 (June 2011): 66-90.
} 
Syaifuddin, et. al.

Lembaga pendidikan yang terbuka, akan selalu responsif dalam menghadapi beragam situasi dan tantangan. Madrasah yang kebanyakan merpakan kelanjutan dari sistem madrasah, memiliki nilainilai yang sengaja dibiasakan dan ditanamkan kepada warganya. Madrasah yang dipayungi pesantren umumnya sarat dengan nilai-nilai kejujuran, kesederhanaan, kebersamaan, tanggung jawab, tolongmenolong, gotong rotong, kemandirian, dan soliaritas yang tinggi. ${ }^{30}$ Nilai-nilai ini menjadi modal tersendiri bagi madrasah untuk merangsang orang menyekolahkan anaknya di madrasah.

Keberadaan MTs. BBI di tengah masyarakat Non Muslim pada awalnya kurang mendapat tempat di hati masyarakat. Sehingga pengembangan lembaga sering mengalami hambatan. Akan tetapi karena strategi beradaptasi dan promosi yang bersifat persuasif dengan modal toleransi, akhirnya lembaga ini pun diterima oleh masyarakat. Masyarakat Hindu menerima keberadaan lembaga ini dengan baik dan dapat hidup damai dengan pihak pesantren. Pihak pesantren pun menyebarkan ajaran damai kepada masyarakat Hindu.

Penerimaan masyarakat Non Muslim terhadap keberadaan lembaga MTs. BBI dapat dilihat dari ungkapan Yuli Saiful Bahri:

"Penerimaan masyarakat non Muslim terhadap lembaga pesantren yang di dalamnya ada madrasah terlihat dari kemauan mereka menjual tanah yang ada di sekitar pesantren. Mereka tidak pernah menyoal tentang mau dibuat apa tanah yang dibeli tersebut. Mereka tidak resisten, terutama dari kelompok orang tua. Kalau dari kelompok anak mudanya, memang awalnya resisten terhadap keberadaan lembaga. Mereka kalau lewat selalu membleyer-bleyer sepeda motor. Tapi lama-kelamaan hal itu hilang dengan sendirinya. Apalagi ketika mereka tahu bahwa ternyata di lembaga ini ada orang-orang yang beragama Hindu ikut mengajar dan bekerja di sini."31

Saat ini masyarakat Hindu (Non Muslim) di sekitar MTs. BBI bisa menerima keberadaan madrasah. Pada awal-awal berdirinya, ada semacam teror dari kelompok pemuda, sekitar 10-15 sepeda motor masuk pagar lalu geber-geber dan kemudian pergi pergi lagi. Setelah itu lembaga mengadakan lomba yang bisa diikuti oleh semua warga masyarakat. Lomba yang dimaksud adalah jenis permainan basket, voley, tenis meja, dan masyarakat desa pun menyambutnya dengan dukungan. Ini memang bagian dari strategi lembaga untuk diterima di masyarakat yang notabene Non Muslim.

Strategi lain yang juga dilakukan oleh MTs. BBI adalah merekrut guru-guru dari kelompok mereka yang Non Muslim dan beragama Hindu. Hal ini dilakukan untuk menghilangkan atau meminimalisir resistensi masyarakat sekitar yang notabene non Muslim beragama Hindu. Kelompok minoritas memang harus pandai-pandai beradaptasi dengan kelompok mayoritas. Istilah minoritas mengandung sekumpulan teori prejudis yang tersembunyi (hidden) dan mewakili kepentingan kelompok dominan dalam tatanan sosial yang ada. ${ }^{32}$ Kelompok minoritas bukan lagi digunakan sebagai label umum bagi orang-orang yang menjadi subjek dari diskriminasi kolektif. Penekanan pada kuantitas dapat dikatakan kurang mendasar dan mengaburkan ketimpangan kekuasaan (powerinequality). Hal yang

\footnotetext{
${ }^{30}$ H.A. Rodli Makmun, "Pembentukan Karakter Berbasis Pendidikan Pesantren: Studi di Pondok Pesantren Tradisional dan Modern di Kabupaten Ponorogo," Cendekia, Vol. 12, No. 2 (Juli-Desember 2014), 231.

${ }^{31}$ Yuli Saiful Bahri (Kepala MTs. Bali Bina Insani), Wawancara pada 25 Agustus 2018.

${ }^{32}$ Meyers, "Minority Group: An Ideological Formulation", 7.
} 
lebih penting dalam konteks ini adalah sebuah istilah yang tidak membubuhkan kesalahan tersebut dan secara eksplisit membubuhkan hubungan kekuasaan (powerrelations) yang membawa dan mempertahankan eksistensi kelompok tertentu.

Meyers, sebagaimana Blauner, menyatakanbahwa orang yang menjadi bagian dari kelompok dan menjadi target kolektif dari perlakuan prejudis, diskriminasi, dan dominasi, termasuk dalam kategori kelompok tertindas (oppressedgroups). ${ }^{33}$ Dalam konteks minoritas Muslim Meliling Karambitan Tabanan Bali, status tersebut tidak hanya berkaitan dengan jumlah komunitas Muslim yang lebih sedikit dibandingkan dengan total populasi penduduk yang tinggal. Tetapi terdapat juga asumsi-asumsi terkait dengan status minoritas, dilihat dari aspek kultur, ekonomi atau politik. ${ }^{34}$

Dari sekian lembaga pendidikan Islam di Bali, MTs. Bali Bina Insani yang berada di komplek pesantren memang betul-betul tumbuh di tengah-tengah masyarakat Non Muslim. Lembaga-lembaga pendidikan Islam yang lain, umumnya tumbuh dan berkembang di tengah-tengah komunitas Muslim. Hal ini menjadi tantangan tersendiri dalam hal keberterimaan masyarakat sekitar. MTs. BBI berada di desa Meliling, sebuah desa adat yang tidak mudah menerima komunitas beda agama. Akan tetapi karena pendekatan dan strategi-strategi tertentu yang dilakukan oleh lembaga, maka keberadaannya pun menjadi diterima.

Memang pernah terjadi resistensi yang cukup tinggi dari salah seorang kepala desa, dimana lembaga yang akan dapat bantuan dana pembangunan asrama 3 lantai sebesar 3 milyard, dihalanghalangi oleh kepala desa dan tidak disetujui sehingga pembangunan itu pun gagal karena dana bantuannya tidak jadi dapat dicairkan dan dikembalikan ke kas Negara. Itu hanya oleh salah satu oknum kepala desa, dan sekarang kepala desa yang bersangkutan sudah diganti karena berhalangan dengan mengalami sakit. Untuk kepala desa yang sekarang cukup kooperatif dengan keberadaan lembaga MTs. BBI. ${ }^{35}$

Saat ini respon masyarakat sekitar Madrasah Tsanawiyah Bali Bina Insani sangat baik terhadap lembaga ini. Sudah tidak ada masalah terkait dengan keberterimaan masyarakat sekitar terhadap MTs. BBI. Sebagaimana pengakuan Purnomo:

"Selama ini gak ada masalah pak dengan masyarakat sekitar, karena kita selalu terbuka dan berusaha selalu membangun hubungan baik dengan masyarakat. Kalau misalnya di sekitar masyarakat sini ada upacara ngaben, atau ada orang meninggal, pasti ada perwakilan lembaga yang berkunjung, kalau pas idul adha kita berkorban kambing, kita undang warga Hindu untuk makan bersama. Kalau daging sapi, mereka ada yang mau dan ada yang tidak mau." ${ }^{\prime 36}$

Meski MTs. BBI merupakan lembaga pendidikan Islam yang berada di tengah-tengah atau daerah Non Muslim, namun tetap dapat melaksanakan proses pendidikannya, karena secara umum

\footnotetext{
${ }^{33}$ Meyers, "Minority Group: An Ideological Formulation," 11.

${ }^{34}$ Ted Robert Gurr, "The Status of Minorities at Risk: Inequalities and Discrimination", dalam Minorities at Risk: A Global View of Ethnopolitical Conflicts (Washington DC: Institute of Peace Press, 1993), 38-40.

${ }^{35}$ Yuli Saiful Bahri (Kepala MTs. Bali Bina Insani), Wawancara pada 25 Agustus 2018.

${ }^{36}$ Purnomo (Wakil Kesiswaan MTs. Bali Bina Insani), Wawancara pada 25 Agustus 2018.
} 
Syaifuddin, et. al.

masyarakat sudah menerima keberadaannya. Hal itu tidak terlepas dari pendekatan-pendekatan persuasif yang dilakukan pihak lembaga dengan ragam macam modelnya. Dengan demikian pendekatan persuasif, adaptif, inklusif, akulturatif, toleran memang penting untuk diterapakan demi eksistensi sebuah lembaga, meski lembaga tersebut minoritas di daerahnya.

\section{E. Tantangan dan Daya Dukung Marketing Education MTs. BBI di Daerah Non Muslim}

Diantara tantangan yang dihadapi oleh MTs. Bali Bina insani dalam mengembangkan lembaga pendidikannya adalah keberadaan masyarakat Non Muslim yang dominan di daerahnya. Umat Muslim minoritas di Tabanan Bali. Umat mayoritas adalah Hindu. Memang masyarakat Hindu punya ajaran toleransi sehingga mau bersikap legowo dengan keberadaan minoritas Muslim di daerah kekuasaannya. Akan tetapi sikap toleran masyarakat Hindu menjadi berkurang akibat dampak dari perilaku bom bunuh diri oleh Amrozi dan kawan-kawan pada tahun 2000-an.

Gara-gara Bom Bali, umat Muslim semakin terpojok dan lembaga pendidikan Islam semakin tersudut. Selalu ada upaya umat Hindu Bali untuk memojokkan kelompok Islam yang minoritas di Bali, terutama setelah kejadian bom Bali. Umpamanya, ada kebijakan, bahwa umat Hindu Bali akan diberi sanksi apabila membeli mie goreng, bakso, tahu goreng, dan makanan atau jasa lain yang disediakan umat Islam. ${ }^{37}$

Pernah juga diberlakukan peraturan adat yang member sanksi dengan denda hingga Rp. 50.000 bagi orang Hindu Bali yang membeli makanan bakso Jawa atau bakso orang Islam. Isu itu disertai dengan usaha koperasi Bali yang memfasilitasi penjualan bakso-bakso yang bahannya dari babi. Upaya ini sempat menjadi fenomena di Bali. Tujuan eksplisitnya untuk memberdayakan ekonomi warga Hindu Bali, tetapi komunitas Islam menilai bahwa usaha ini secara implisit bertujuan untuk mematikan usaha ekonomi umat Islam yang secara umum mereka adalah pendatang agar ekonominya mati dan kembali pulang kampung. ${ }^{38}$ Diterapkan juga aturan di Bali, untuk memiliki KTP Bali, umat Islam pendatang harus memiliki tanah atau rumah sendiri dengan memperlihatkan sertifikat rumah. Tanpa punya sertifikat, meski umat Islam sudah puluhan tahun bertempat tinggal di Bali, maka ia tidak akan pernah diterima sebagai masyarakat Bali dan tetap dianggap sebagai warga liar.

Perseteruan antara kaum Muslimin dengan umat Hindu Bali memuncak pasca terjadinya bom Bali pada tahun 2002. Dalam rangka menetralisir kondisi pertikaian tersebut, para tokoh agama dan masyarakat saat itu meningkatkan frekwensi untuk saling bertemu. Para pemimpin agama bersepakat untuk saling menjaga dan menahan diri. Pertemuan-pertemuan yang dilakukan bertujuan untuk mengendalikan diri warga agar tidak saling bertikai. Hamdan Basyar menyatakan, antara kaum Muslimin dan umat Hindu sepakat bahwa kejadian bom Bali tidak bisa dikaitkan dengan ajaran agama, etnis dan

\footnotetext{
${ }^{37}$ Hanik Yuni Alfiyah, Survival Strategy Pesantren-pesantren di Pulau Hindu Bali Pasca Bom Bali, Laporan Penelitian (Jakarta: Diktis Kemenag RI, 2016).

38 Putu Setia, Bali yang Meradang (Denpasar: Manikgeni, 2006), 20.
} 
kepercayaan. ${ }^{39}$ Meski begitu, setelah kejadian pasca bom Bali tetap menjadi waktu yang sulit bagi kaum Muslimin di Bali. Kaum Muslimin tetap menjadi sasaran tembak kecurigaan, praktik sapaan berubah menjadi cemoohan yang memojokkan keberadaan umat Islam di Bali.

Bom Bali ini menjadi tantangan tersendiri bagi umat Islam dalam berkiprah dan mengembangkan lembaga yang dikelolanya. Umat Islam melakukan strategi-strategi tertentu agar tetap dapat eksis demi terlaksananya pendidikan yang baik untuk masyarakat. Meski tersudut dan selalu dicurigai, umat Islam tetap selalu berusaha menciptakan sejarahnya sendiri. Hal ini sejalan dengan pandangan Marx, bahwa kecenderungan manusia selalu ingin menciptakan sejarahnya sendiri, meskipun tidak dalam situasi dan kondisi yang sesuai dengan pilih mereka. ${ }^{40}$

Hal-hal yang dilakukan lembaga-lembaga pendidikan Islam di Bali (termasuk MTs. BBI) adalah tindakan kolektif agar tetap dapat eksis dalam melaksanakan pendidikannya. Kolektivitas ini memicu sebuah praktik sosial ${ }^{41}$ yang berdampak pada upaya kerjasama dan gotong-royong agar lembaga pendidikan Islam di Bali tetap dapat melaksanakan pendidikannya. Hal ini juga disebabkan karena sebuah kesadaran bahwa generasi bangsa atau anak-anak Muslim tetap selalu butuh belajar di lembaga pendidikan Islam yang terjangkau dalam hal biaya dan aspek-aspek lainnya.

Diantara upaya yang dilakukan lembaga pendidikan Islam dalam mengatasi resistensi umat Hindu di Bali terutama setelah terjadinya bom Bali antara lain: strategi kooperatif, adaptif, dakwah kultural, akulturatif, sikap toleran, mengalah, dan lain sebagainya. Semuanya dilakukan dapat lembaga pendidikan Islam yang minoritas tetap dapat eksis dalam melaksanakan proses pendidikannya. Sikap toleran, praktik inklusif, keterbukaan dan menerima perbedaan dan keberagaman selalu dikedepankan oleh lembaga-lembaga pendidikan Islam di Bali, terutama oleh Madrasah Tsanawiyah Bali Bina Insani (MTs. BBI). ${ }^{42}$

Dalam konteks MTs. BBI, ia menerapkan pendidikan mutikultural ${ }^{43}$ dengan mengakomodir keberadaan umat beragama lain (Non Muslim), untuk menjadi pengajar di lembaganya. ${ }^{44}$ Muatan materi

\footnotetext{
${ }^{39}$ Basyar, Identitas Minoritas di Indonesia.

${ }^{40}$ K. Marx, The Eighteenth Britanaire of Louis Bonaparte (New York: International Publisher, 1963), 15.

${ }^{41}$ Dapat ditelusuri dalam Teori Giddens mengenai Praksis Sosial, lihat Ira J. Cohen, "Teori Strukturasi dan Praksis Sosial", dalam Anthony Giddens \& Jonathan Turner, Social Theory Today, Terj. Yudi Santoso(Yogyakarta: Pustaka Pelajar, 2008), 471.

${ }^{42}$ MTs. BBI selalu mengedepankan persamaan daripada perbedaan. Dunia pendidikan pendidikan Islam memang perlu menawarkan konsep dan praktik pendidikan yang mengajarkan pencarian titik temu kesamaan dan bukan perbedaan, pola pendidikan semacam ini sering disebut dengan pendidikan multikultural, yang megandung ajaran-ajaran: persamaa, demokrasi, pluralisme, dan kebebasan. Lihat Hasan Baharun \& Robiatul Awwaliyah, "Pendidikan Multikultural dalam Menanggulangi Narasi Islamisme di Indonesia", Jurnal Pendidikan Agama Islam, Vol. 5, No 2 (Surabaya: PAI-FTK-UINSA, 2017), 230.

${ }^{43}$ Lembaga pendidikan Islam perlu menerapkan pendidikan multikultural, meskipun membutuhkan strategi tersendiri dalam penyesuaian dan implementasinya. Dalam pendidikan multikultural identitas diasah melalui interaksi budaya internal dan eksternal. Identitas dan budaya lokal merupakan muatan yang harus ada dalampendidikan multikultural. Lihat A. Suradi, "Penanaman Religiusitas Keislaman Berorientasi pada Pendidikan Multikultural di Sekolah", Jurnal Pendidikan Agama Islam, Vol. 6, No. 1 (Surabaya: PAI-FTK-UINSA, 2018), 31.

${ }^{44}$ Peran pengajar amat penting dalam mengembangkan materi ajar berwawasan multikultural. Guru berperan strategis dalam mengondisikan kelas yang berperspektif multikultural. Di antara peran guru dalam mengondisikan kelas
} 
Syaifuddin, et. al.

multikultural diberikan lewat beragam metode yang didasarkan pada psikologi budaya, musyawarah atau diskusi kelompok terkait nilai-nilai keberagaman yang dimungkinkan dapat meghasilkan inovasi, kreativitas, dan komunikasi lintas budaya. ${ }^{45} \mathrm{Hal}$ ini dipraktikkan di MTs. BBI agar keberadaannya semakin dapat beradaptasi dengan masyarakat sekitar yang hampir 100\% non Muslim atau Hindu. Dengan pendekatan-pendekatan sebagaimana tersebut di atas, maka tantangan yang dihadapi oleh MTs. BBI relatif teratasi dan keberadaan lembaga pendidikan Islam (MTs. BBI) dapat tetap eksis dalam pelaksanaan pendidikannya.

Sementara itu, terdapat daya dukung dari keberadaan MTs. Bali Bina Insani. Diantara daya dukung yang ada adalah loyalitas kepengurusan madrasah. Mengingat kelompok ini adalah minoritas, biasanya kelompok minoritas itu memiliki loyalitas yang tinggi. Loyalitas antar pendiri dan pengurus madrasah ini menjadi modal awal untuk daya dukung dari pegembangan dan pemasaran MTs. BBI. Meski Sumber Daya Manusia (SDM) -nya terdiri dari unsur yang beragam, namun mereka loyal dan komitmen untuk mengembangkan lembaga pendidikan Islam dimana mereka mengabdi.

Di samping itu, jaringan pertemanan dari pendiri lembaga MTs. BBI juga menjadi daya dukung dari keberadaan MTs. BBI. Jaringan pertemanan ini dimanfaatkan betul untuk membangun kerjasama antar para pihak demi kelangsungan madrasah. Yuli Saiful Bahri menyatakan:

"Alhamdulillah, dalam perkembangannya, Allah menakdirkan suatu ketika ayahanda (H. Ketut Imaduddin Jamal-Pendiri BBI) sedang berangkat tugas ke Jakarta, duduk di sebelahnya teman dari dinas peternakan, lalu terjadi perbincangan dan mereka sepakat membangun kerjasama. Sehingga sejak tahun 2008 ada MoU bantuan 40 ekor sapi. Kami berikan 20 ekor sapi untuk potong 20 untuk diternakkan. Kita sebar, kita manfaatkan masyarakat untuk bersedia menernak. Akhirnya kita bangun kerjasama dengan masyarakat sekitar yang notabene beragama Hindu dalam hal peternakan sapi. Sampai sekarang masih ada sapi yang diternakkan. Kalau ada yang dipotong nunggu idul adha saja, kecuali tahun ini belum ada informasi, biasanya sudah ada informasinya, atau mungkin sudah lapor ke ayah anda tapi saya belum dapat informasinya. Ada juga yang lewat jalur informasi lalu saya sampaikan ke ayahhanda. Posisi ayahanda sebagai ketua pengadilan kantor agama juga menjadi daya dukung dari pemasaran madrasah ini. Kerjasama juga terjadi dalam hal jasa yang lain. misalnya, ketika ayahanda cari sopir, akhirnya ada warga Hindu dari masyarakat sekitar yang melamar dan kemudian diterima oleh ayahanda. Sopir tersebut juga dimanfaatkan untuk tenaga security di lembaga kami. Madrasah juga terbuka untuk menerima tenaga pengajar yang beragama Hindu. Ini juga menajdi daya dukung bagi keberadaan madrasah. ${ }^{\prime 46}$

Adanya kerjasama dengan warga sekitar, menjadi daya dukung tersendiri bagi keberadaan MTs.

BBI. Kerjasama tidak hanya berlaku dalam hal jasa tenaga kasar tetapi juga tenaga pengajar. Guru-guru

multikultural adalah: Pertama, guru harus demokratis, dalam perkataan, sikap dan perbuatannya tidak boleh diskriminatif. Kedua, guru harus peduli pada kejadian-kejadian tertentu yang terkait dengan agama. Sebagai contoh, ketika terjadi bom Bali (I dan II) atau bom bunuh diri di banyak tempat, guru yang berwawasan multikultural harus menjelaskan rasa prihatinannya pada kejadian tersebut. Guru harus menerangkan bahwa esensi ajaran Islam adalah menciptakan kedamaian bagi manusia, maka pemboman dan segala wujud kekerasan merupakan sesuatu yang terlarang dalam Islam. Guru harus memberikan pemahaman tentang pentingnya dialog dan musyawarah dalam menyelesaikan permasalahan yang berkaitan dengan keragaman budaya, etnis, golongan, agama dan aliran. Lihat Husniyatus Salamah Zainiyati, "Pendidikan Multikultural: Upaya Membangun Keberagamaan Inklusif di Sekolah", Islamica, Vol. 1, No. 2 (Surabaya: PPs IAIN Sunan Ampel, Maret 2007), 141-142.

${ }^{45}$ Brian W. Haas, "Enhancing the Intercultural Competence of College Students: A Consideration of Applied Teaching Techniques", International Journal of Multicultural Education (Vol. 21, No. 2, 2019), 81.

${ }^{46}$ FGD pada 1 September 2018. 
Hindu dari warga sekitar dijadwal mengajar bahasa Bali, prakarya, kesenian, IPS, Matematika, dan lain sejenisnya. ${ }^{47}$ Dengan adanya kerjasama ini maka masyarakat sekitar menjadi tidak resisten.

Daya dukung yang lain dari keberadaan MTs. BBI adalah keterjangkauan biaya sekolah di madrasah ini. Biaya sekolah di madrasah ini relatif murah, sehingga dapat diakses oleh masyarakat secara luas. Oleh karena masyarakat sekitar madrasah ini adalah warga Hindu, maka yang akses pendidikan di lembaga ini rata-rata warga dari Muslim dari luar daerah.

Hal yang menjadi daya dukung juga bagi keberadaan MTs. BBI ini adalah sikap toleran dengan segala keberagaman dan perbedaan. Sehingga lembaga pendidikan Islam ini sering mendapat perhatian dari lembaga publik untuk kemudian berminat berkunjung ke lembaga ini. Sebagaimana diceritakan oleh Yuli Saiful Bahri:

"Pernah ada kunjungan dari asosiasi pendidikan Kashmir. Mereka hadir kesini tahun 2016 lalu kita minta untuk bicara tentang pendidikan. Pada tahun yang sama kita juga dapat kunjungan dari lembaga Bali Demokrasi Forum, sebuah lembaga yang dibentuk oleh Pak SBY. Pertemuan yang dilakukan di lembaga kami merupakan pertemuan yang ke-9 dengan melibatkan 96 perwailan negara yang hadir di sini. Pada saat pertemuan, guru yang beragama Hindu membuat testimoni di depan mereka tentang perlakuan kelompok mayoritas Muslim di kompleks madrasah kepada mereka yang minoritas. Para tamu terharu dan ada yang menangis karena kagum dengan toleransi yang ada di lembaga kami. Guru Hindu (Suardani) mengaku bahwa sudah 13 tahun mengabdi di MTs. Bali Bina Insani, dan perlakuan warga Muslim di kompleks madrasah sangat baik, sehingga kami jatuh cinta pada lembaga ini." ${ }^{\prime 48}$

Sikap toleran (tasamuh) memang sudah terinternalisasi kedalam diri SDM madrasah (MTs. BBI), sehingga meski beda agama di dalam satu lembaga, mereka dapat hidup rukun dan damai. Oleh karena begitu tolerannya, pihak lembaga tidak suka mengedepankan simbol-simbol agama. Kalau ada kegiatan di dalam lembaga, pengeras juara jarang digunakan. Kalaupun menggunakan pengeras suara, diusahakan yang dibunyikan hanya speaker dalam dan sebisa mungkin suara tidak keluar ke masyarakat. ${ }^{49}$ Kalau ada siswa yang keluar ke masyarakat, dipesan tidak perlu memakai kopyah, meski dalam keseharian mereka memakai kopyah ketika proses pembelajaran di kelas. Hal ini juga menjadi daya dukung luar biasa bagi lembaga pendidikan Islam (MTs. BBI).

Di MTs. BBI tidak pernah ada pemaksaan untuk berbusana tertentu sebagaimana tradisi berpakaian ala Muslim atau Muslimah. Para guru yang beragama Hindu tetap dibiarkan berpakaian sebagaimana mereka berpakaian. Bagi yang tidak berjilbab, ya tetap tidak berjilbab. Bagi yng biasa pakai celana jeans, ya dibiarkan pakai jeans. Hal itu menambah kenayamanan mereka dalam mengabdi dan berkiprah di MTs. BBI. Ketika berkumpul antara guru Muslim dan Hindu mereka bisa merasakan kenyamanan dan tidak ada gap atau sentiment agama. ${ }^{50}$

Sebagaimana guru yang saling menghormati kepada guru lainnya, para siswa juga saling menghormati kepada gurunya, meski gurunya non Muslim. Dalam pengakuan guru yang non Muslim (Hindu) dikatakan bahwa para siswa sangat hormat kepada mereka: "para siswa terbuka pak, walaupun

\footnotetext{
${ }^{47}$ Yuli Saiful Bahri (Kepala MTs. Bali Bina Insani), Wawancara pada 25 Agustus 2018.

${ }^{48}$ Yuli Saiful Bahri (Kepala MTs. Bali Bina Insani), Wawancara pada 25 Agustus 2018.

${ }^{49}$ Turoihan (Pengurus Kantin Putra Pesantren Bali Bina Insani), Wawancara pada 26 Agustus 2018.

${ }^{50}$ Sumartono (Guru di Mts. Bali Bina Insani), Wawancara pada 26 Agustus 2018.
} 
Syaifuddin, et. al.

saya dan teman-teman itu non-Muslim, tetap kalau ketemu mereka salaman dan cium tangan, itu sudah biasa." 51

Meski berbeda agama dengan para siswa, para guru yang Hindu tidak punya pikiran untuk mengajak para siswa mengenal dan masuk pada agama Hindu. Dalam hal ini mereka netral. Soal agama adalah urusan masing-masing. Para guru Hindu hanya mengajarkan materi pelajaran yang sesuai dengan tugas mereka. Oleh karena itu, meski beda agama, tapi beda agama tersebut tidak menjadi penghalang untuk melaksanakan proses pembelajaran yang baik.

Hal ini menjadi daya dukung bagi keberadaan lembaga pendidikan Islam (MTs. BBI), sehingga dapat tetap eksis dan dapat melakukan promosi dengan beragam strategi halus (soft) agar berkembang eksistensinya. Strategi pemasaran pendidikan dilakukan dengan modal pemanfaatan jaringan kolega, media sosial online, jaringan alumni, dan beragam strategi lainnya.

\section{F. Simpulan}

Beberapa simpulan dapat disampaikan sebagai berikut. Pertama, diantara strategi yang dilakukan oleh pihak Madrasah Tsanawiyah Bali Bina Insani dalam memasarkan lembaga pendiikannya di daerah non Muslim adalah melakukan promosi lembaga secara soft (halus). Media online dimaksimalkan dalam promosi madrasah. Disamping itu, jaringan alumni dan wali santri dimanfaatkan betul untuk memasarkan madrasah dan mendulang santri atau siswa sebanyak-banyaknya. Jaringan kolega juga dimanfaatkan untuk mendukung keberadaan lembaga. Promosi-promosi melalui media televise ketika diundang talk show juga dimanfaatkan oleh pihak madrasah.

Kedua, masyarakat non Muslim yang notabene mayoritas di daerah Madrasah Tsanawiyah Bali Bina Insani menerima keberadaan madrasah dengan sikap mau bekerjasama. Diantara kerjasama yang dilakukan adalah masyarakat sekitar yang mempunyai usaha dagangan beras bersedia menyuplai beras ke pihak madrasah. Masyarakat sekitar madrasah yang non Muslim juga mau bekerja di lingkungan madrasah. Madrasah dengan sikap keterbukaannya menerima SDM non Muslim untuk bekerja di lingkungannya. Kerjasama dalam bidang peternakan sapi juga dilakukan antara pihak madrasah dengan masyarakat sekitar yang beragama Hindu.

Ketiga, Diantara tantangan yang dialami pihak Madrasah Tsanawiyah Bali Bina Insani dalam pemasaran lembaganya adalah warga sekitar madrasah mayoritas berbeda agama dengan pihak madrasah. Hal ini menjadi tantangan tersendiri, sebab dalam hal visi misi lembaga jelas tidak sejalan dengan visi misi warga sekitar dari aspek worldview keagamaan. Sementara daya dukung yang dimiliki madrasah dalam pemasaran lembaganya adalah madrasah bersikap terbuka dan toleran terhadap segala perbedaan dan keberagaman. Hal ini membuat pihak madrasah dapat bekerjasama dengan baik

\footnotetext{
${ }^{51}$ Suardani (Guru MTs Bali Bina Insani beragama Hindu), Wawancara pada 26 Agustus 2018.
} 
dengan warga sekitar yang hampir keseluruhannya beragama Hindu. Maka madrasah dengan segala keterbatasannya dapat tetap eksis di lingkungan masyarakat non Muslim, bahkan cenderung progresif.

\section{G. Referensi}

Alfiyah, Hanik Yuni. Survival Strategy Pesantren-pesantren di Pulau Hindu Bali Pasca Bom Bali. Laporan Penelitian. Jakarta: Diktis Kemenag RI, 2016.

Arif, Mahmud. Panorama Pendidikan Islam di Indonesia; Sejarah, Pemikiran dan Kelembagaan. Yogyakarta: Idea Press, 2009.

Asrohah, Hanun. "The Dynamics of Pesantren: Responses toward Modernity and Mechanism in Organizing Transformation" Journal of Indonesian Islam. Vol. 05, No. 01, June 2011.

Basyar, M. Hamdan. Identitas Minoritas di Indonesia: Kasus Muslim Bali di Gianyar dan Tabanan. Jakarta: LIPI, 2010.

Brosur Lembaga Pendidikan Bali Bina Insani Yayasan La Royba, Tahun 2018.

Baharun, Hasan \& Robiatul Awwaliyah. "Pendidikan Multikultural dalam Menanggulangi Narasi Islamisme di Indonesia".Jurnal Pendidikan Agama Islam.Vol. 5, No 2, Surabaya: PAI-FTK-UINSA, 2017.

Dhofier, Zamakhsyari.Tradisi Pesantren: Studi tentang Pandangan Hidup Kiai.Cet. VI. Jakarta: LP3ES, 1994.

Furchan, Arief. Transformasi Pendidikan Islam di Indonesia; Anatomi Keberadaan Madrasah dan PTAI. Yogyakarta: Gama Media, 2004.

Giddens, Anthony, \& Jonathan Turner. Social Theory Today.Terj. Yudi Santoso.Yogyakarta: Pustaka Pelajar, 2008

Gurr, Ted Robert."The Status of Minorities at Risk: Inequalities and Discrimination", dalam Minorities at Risk: A Global View of Ethnopolitical Conflicts. Washington DC: Institute of Peace Press, 1993.

Haas, Brian W. "Enhancing the Intercultural Competence of College Students: A Consideration of Applied Teaching Techniques".International Journal of Multicultural Education.Vol. 21, No. 2, 2019.

http://www.ppbalibinainsani.com.8 Maret 2018.

Idi, Abdullah, dan Toto Suharto. Revitaslisasi Pendidikan Islam. Yogyakarta: Tiara Wacana, 2006.

Kotler. Manajemen Pemasaran. Jakarta: Prenhallindo, 1997.

Machali, Imam. Manajemen Pemasaran Jasa Pendidikan Madrasah, dalam Antologi Kependidikan Islam: Kajian Pemikiran Pendidikan Islam dan Manajemen Pendidikan Islam. Yogyakarta: Jurusan KI Fakultas Tarbiyah, 2010.

Marx, K. The Eighteenth Britanaire of Louis Bonaparte.New York: International Publisher, 1963.

Meyers, Barton."Minority Group: An Ideological Formulation," Social Problems. Vol. 32, No. 1, Dilematic Issue on Minorities and Social Movements. October, 1984.

Makmun, H.A. Rodli. "Pembentukan Karakter Berbasis Pendidikan Pesantren: Studi di Pondok Pesantren Tradisional dan Modern di Kabupaten Ponorogo".Cendekia. Vol. 12, No. 2, Juli-Desember 2014.

Profil Madrasah Tsanawiyah Bali Bina Insani Yayasan La Royba, Tahun 2018.

Pujiastuti, Tri Nuke."Problematika Minoritas Muslim di Filipina, Thailand, dan Myanmar": Catatan Pendahuluan, dalam Riza Sihbudi (ed).Problematika Minoritas Muslim di Asia Tenggara: Kasus Mora, Pattani dan Rohingya. Jakarta: PPW-LIPI, 2000. 
Syaifuddin, et. al.

Ramayulis.IImu Pendidikan Islam. Jakarta: Kalam Mulia, 1994.

Salahuddin, Nadir. "Dinamika Konstruksi Identitas: Pengalaman Minoritas di Muangthai, Filipina dan Singapura", Makalah disampaikan dalam Diskusi Terbatas Minoritas Muslim di Asia Tenggara di IAIN Sunan Ampel. Surabaya, 6 Juli 2000.

Setia, Putu.Bali yang Meradang.Denpasar: Manikgeni, 2006.

Suradi, A. "Penanaman Religiusitas Keislaman Berorientasi pada Pendidikan Multikultural di Sekolah".Jurnal Pendidikan Agama Islam Vol. 6, No. 1, Surabaya: PAI-FTK-UINSA, 2018.

Zainiyati, Husniyatus Salamah. "Pendidikan Multikultural: Upaya Membangun Keberagamaan Inklusif di Sekolah." Islamica. Vol. 1, No. 2, Surabaya: PPs IAIN Sunan Ampel, Maret 2007.

\section{Data Lapangan:}

FGD pada 1 September 2018.

Nur Fadhilah (Guru Sejarah Kebudayaan Islam MTs. BBI), Wawancara pada 25 Agustus 2018.

Observasi pada 18 Agustus 2018.

Purnomo (Wakil Kesiswaan MTs. Bali Bina Insani), Wawancara pada 25 Agustus 2018.

Suardani (Guru MTs Bali Bina Insani beragama Hindu), Wawancara pada 26 Agustus 2018.

Sumartono (Guru di Mts. Bali Bina Insani), Wawancara pada 26 Agustus 2018.

Turoihan (Pengurus Kantin Putra Pesantren Bali Bina Insani), Wawancara pada 26 Agustus 2018.

Yuli Saiful Bahri (Kepala MTs. Bali Bina Insani), Wawancara pada 25 Agustus 2018. 